\title{
Extraction of Nanocrystals from Millet (Eleusine Coracana) Husk Waste : Optimization using Box Behnken Design Method in Response Surface Methodology (Rsm)
}

\section{Banza Musamba}

PhD student

Hilary Rutto ( $\nabla$ hilaryr@vut.ac.za )

Vaal University of Technology

\section{Research}

Keywords: Cellulose nanocrystals, Extraction, Response surface method, Box Behnken

Posted Date: August 31st, 2021

DOl: https://doi.org/10.21203/rs.3.rs-824085/v1

License: (c) (1) This work is licensed under a Creative Commons Attribution 4.0 International License. Read Full License 


\section{Abstract}

Cellulose nanocrystals (CNCs) have unique and diverse applications in the various fields of developing nanomaterials. In this work, cellulose nanocrystals were extracted from millet husk residue waste using a homogenized acid hydrolysis method. The effects of the process variables namely; homogenization speed, acid concentration and acid to cellulose ratio on the yield and swelling capacity were investigated and optimized using the Box Behnken design method in response surface methodology. The cellulose and nano-cellulose obtained were characterized using transform infrared microscopy (FTIR), X-ray diffraction (XRD), thermogravimetric analysis (TGA), and scanning electron microscopy (SEM). The numerical optimization analysis results showed that the maximum yield of CNCs from cellulose was $93.12 \%$ and obtained at homogenization speed, acid concentration, and acid to cellulose ratio of 7464.0 rpm, $63.40 \mathrm{wt} \%$, and $18.83 \mathrm{wt} \%$ respectively. The maximum swelling capacity of $2.81 \%$ was obtained at homogenization speed, acid concentration, and acid to cellulose ratio of $8000 \mathrm{rpm}, 62.5 \mathrm{wt} \%$, and $25 \mathrm{wt}$ $\%$ respectively. A mathematical model was obtained to predict the yield and the swelling capacity of cellulose nanocrystals with $\mathrm{R}^{2}$ of the value of $98.9 \%$ and $97.9 \%$ respectively. The TGA showed that the thermal stability of cellulose was higher than that of CNCs, FTIR results showed functional groups of CNCs and cellulose were similar, SEM image of CNCs is porous and displayed narrow particle size and needle-like morphology as compared to cellulose and XRD pattern presented an increase in the intensity of CNCs.

\section{Introduction}

In nanotechnology, the modification and synthesis of nanomaterials with distinct configurations and functions are gaining increasing interest due to their multiples potential uses which are applicable in nanocarriers, packaging materials, cosmeceutical, drug delivery systems, biomaterials, water treatment, and food components (Leszczy et al. 2018; Niamsap et al. 2019). However, most of the chemicals used in the production of nanomaterials come from petroleum-derivated resources which are toxic and detrimental to the environment. Alarms about global warming towards attaining sustainable development are of great concern and there is a critical need to substitute the traditional non-renewable materials with renewable resources (Onur et al. 2018). Also, the ability to convert abundant and cheap materials to produce high-value products offers great benefits.

Renewable energy is by the future the fastest-growing fuel source and giving about $14 \%$ of principal energy (Abdelraof et al. 2019). Cellulose fibers synthesized from animals, plants, and bacteria are the most available resources that can be used as renewable materials. Cellulose is the furthermost specific kind of linear homopolymer produced in billions of tons yearly, consisting of $\beta$-D glucoproprenose $(1 \rightarrow 4)$ fused through the hydrogen bonds (Lei et al., 2019). Cellulose predominately exists in the cell walls of plants and is crucial for the rigidity of the cell wall (Hynninen et al. 2019). Cellulose is applied in many applications because it is stable, biodegradable, environmentally friendly, and readily available (Awang et al.2019). 
In modern years, the use of cellulose has been in the areas of nanotechnology materials (Du et al. 2019). Acidic/alkaline hydrolysis extraction methods with sulfuric acid proceeds with the removal of more amorphous regions within the structures of cellulose, while the crystalline parts called nanoparticles were undamaged (Wu et al. 2018). Cellulose nanocrystals can be produced via alkaline/acidic hydrolysis, steam explosion, enzymatic hydrolysis, high-pressure symmetry, sonication, and grinding processes (Hemmati et al. 2018; Du et al. 2019),

The physicochemical features of cellulose nanocrystals can differ depending on the technique of extraction and the source of cellulose. Cellulose nanocrystals have been extracted from by alkali/hydrolysis methods using wall nutshells, banana peels, palm date fiber, sawdust, sago seed, and waste paper (Hemmati et al. 2018; Meng et al. 2019; Shafiei et al. 2010; Oyewo et al. 2019; Purushothaman, 2016; Souza et al. 2017).

The two major millets that are grown in Sub-Saharan Africa are the pearl millet (Pennisetum glaucum) and finger millet (Eleusine coracana) for nutritional values as it contains high amounts of calcium (Gopala et al. 1989). After harvesting, the millet is used and husks are disposed of as agricultural waste which can be used as a source of cellulose.

To date few or no known works, on the optimization of the extraction of cellulose nanocrystals from finger millet husk using response surface methodology. The response surface methodology is employed to analyze the impact of process parameters and to predict the optimum condition at a minimized number of experiments. Optimization and studying the effect of process variables can be done using 3level factorials, central composite design, hybrid, pentagonal, hexagonal, D-optimal, distance-based, and box Behnken (Zolgharnein et al. 2017).

In this study, the Box Behnken method in response surface methodology tool was used to determine the optimum conditions for the extraction of cellulose nanocrystals from millet husk. The selection of the design method was due to its capability which allows multiple responses. The individual numerical factor is varied over three levels and has fewer runs associated with the three-level factorials (Montgomery, 2005). This method does not require several central points since the points on the surface are closer towards the midpoint. The effects of process variables namely; homogenization speed, acid concentration, and acid to cellulose ratio on the yield and swelling of CNCs were investigated and optimized numerically. Analysis of variance (ANOVA) was also used as a statistical and diagnostic checking test tool. Additionally, cellulose and cellulose nanocrystal was characterized using X-ray Diffraction (XRD), Scanning electron microscope (SEM), Fourier transform infrared spectroscopy (FTIR), and Thermogravimetric analysis (TGA).

\section{Materials And Methods \\ 2.1 Materials}


Millet husks residue used were obtained from a millet processing farm in Kenya. Sulfuric acid, sodium chlorite, sodium hydroxide, acetic acid, ethanol, and dialysis bag were supplied by Sigma Aldrich and Merck Chemical South Africa and were of analytical grade.

\subsection{Production of cellulose from millet husk waste}

The millet husk waste was washed, air-dried, milled, and sieved with a 45 mesh sieve. The oil was removed from the ground husk by solvent extraction with ethanol at $65^{\circ} \mathrm{C}$ for 6 hours. The unextracted sample was dried in on oven at $65^{\circ} \mathrm{C}$ for 15 hours and was stored in a tight polythene bag. $500 \mathrm{~mL}$ of aqueous sodium hydroxide (7.0\%) was mixed with $50 \mathrm{~g}$ of the sample. The mixture was agitated for 60 minutes at $25^{\circ} \mathrm{C}$. The pretreated sample was filtered at $25^{\circ} \mathrm{C}$ before being repeatedly rinsed with $90 \%$ ethanol to remove wax and oil. After that, the sample was dried in an oven for 18 hours at $65^{\circ} \mathrm{C}$. The sample was further mixed with $200 \mathrm{~mL}$ deionized water, $1.5 \mathrm{~g}$ sodium chlorite, and $25 \mathrm{~mL}$ acetic acid. The mixture was stirred for 3 hours at $70^{\circ} \mathrm{C}$. The residue was rinsed with a mixture of distilled water and ethanol. The final sample was dried in an oven at $65^{\circ} \mathrm{C}$ for 20 hours. The cellulose obtained was used to produce cellulose nanocrystals.

\subsection{Cellulose nanocrystals extraction}

The acidic hydrolysis technique by (Priscila et al. 2019) was used to produced cellulose nanocrystals from cellulose with $65 \mathrm{wt} \%$ sulfuric acid used. Cellulose was mixed fully with the acid to cellulose ratio $(1: 15,1: 20,1: 25)$ using a homogenizer at speeds of $(4000,6000,8000 \mathrm{rpm})$ for $10 \mathrm{~min}$ at $50{ }^{\circ} \mathrm{C}$. After that, the suspension formed was diluted five times with deionized water to discontinue the hydrolysis process. The sample was further centrifuged for 15 minutes at $10000 \mathrm{rpm}$. The suspension that was left was further centrifuged to get rid of the excess sulphuric acid and the supernatant was disposed of. The suspension was placed in a dialysis bag and diluted with distilled water repeatedly to attain a $\mathrm{pH}$ of 7 . The washed sample was homogenized in an ultrasonic set up for $15 \mathrm{~min}$. The mixture was dried in a drier for 72 hours. To stop the microorganism contamination a drop of chloroform was added and lastly, the cellulose nanocrystal powder was preserved in a tight impenetrable vessel.

\subsection{Physical and chemical properties of cellulose nanocrystals}

\subsubsection{Yield of cellulose nanocrystals}

The CNCs yield was calculated using the technique proposed by (Hemmati et al. 2018). The samples were carefully measured using a precise digital balance. The measurement was done in triplicates the average and standard deviation was recorded. Eq. (1) was used to determine the yield of CNCs.

Yield $(\%)=\frac{m_{1-m_{2}}}{m_{3}} \times 100(1)$

Where $m_{1}(g)$ is the wieght of cellulose nanocrystals with the vial, $m_{2}(g)$ is the wieght of the vial, and $m_{3}$ (g) is the weight of cellulose used. 


\subsubsection{Cellulose nanocrystals swelling capacity}

The swelling capacity of CNCs was determined following the technique recommended by (Zou et al., 2018). Firstly, $2 \mathrm{~g}$ of CNCs sample was weighed and placed in a conical flask. Then, $20 \mathrm{~mL}$ of distilled water was poured into the conical flask. The volume of the sample was measured after being stored for $24 \mathrm{~h}$ at controlled room temperature. The swelling capacity was determined using Eq. (2).

$\operatorname{SWC}(m g / L)=\frac{V_{2}-V_{1}}{m} \times 100(2)$

Where $\mathrm{m}(\mathrm{g})$ is the weight of the cellulose nanocrystals, $\mathrm{V}_{1}(\mathrm{~mL})$ is the volume initial of the CNCs, and $\mathrm{V}_{2}$ $(\mathrm{mL})$ is the volume of the CNCs together with the absorbed water.

\subsection{Experimental design and optimization 2.5.1 RSM-Box Behnken experimental design}

The evaluation of the linear, cubic, and quadratic effects on the yield and the swelling capacity of CNCs was done using the Box Behnken design in RSM. The choice of this design technique was to permit multiple responses and its capability to use three levels of factorials. Each numerical factorial is varied over three levels and has fewer runs compared to the three-level factorials (Montgomery, 2005). Three process variables were studied namely: Homogenization speed(A); acid concentration (B) and acid to cellulose ratio (C). The series of variables using coded values are shown in Table 1. The Box Behnken set of experiments conducted and the results of this study are shown in Table 2.

Table 1

Range of factors and their levels used in the Box Behnken design.

\begin{tabular}{|lllll|}
\hline Variable & $\begin{array}{l}\text { Coded } \\
\text { symbol }\end{array}$ & & Coded level \\
\hline & & -1 & 0 & +1 \\
\hline Homogenization speed(rpm) & A & 4000 & 6000 & 8000 \\
\hline Acid concentration (wt \%) & B & 55 & 62.5 & 70 \\
\hline Acid to cellulose ratio (wt \%) & C & 15 & 20 & 25 \\
\hline
\end{tabular}


Table 2

Box Behnken design and results for yield and swelling capacity of CNCs

\begin{tabular}{|c|c|c|c|c|c|}
\hline Run & $\begin{array}{l}\text { A: Homogenization speed } \\
\text { (rpm) }\end{array}$ & $\begin{array}{l}\text { B: Acid } \\
\text { concentration (\%) }\end{array}$ & $\begin{array}{l}\text { C: Acid to } \\
\text { cellulose ratio }\end{array}$ & $\begin{array}{l}\text { Yield } \\
\text { (\%) }\end{array}$ & $\begin{array}{l}\text { Swelling } \\
\text { (\%) }\end{array}$ \\
\hline 1 & 6000 & 62.50 & 20.00 & $\begin{array}{l}87 \pm \\
1.8\end{array}$ & $2.6 \pm 2.9$ \\
\hline 2 & 4000 & 55.00 & 20.00 & $\begin{array}{l}72 \pm \\
2.3\end{array}$ & $3.7 \pm 1.5$ \\
\hline 3 & 8000 & 62.50 & 15.00 & $\begin{array}{l}85 \pm \\
1.1\end{array}$ & $2.7 \pm 3.8$ \\
\hline 4 & 6000 & 55.00 & 25.00 & $\begin{array}{l}78 \pm \\
1.2\end{array}$ & $3 \pm 1.8$ \\
\hline 5 & 6000 & 55.00 & 15.00 & $\begin{array}{l}80 \pm \\
1.8\end{array}$ & $3.1 \pm 2.6$ \\
\hline 6 & 8000 & 70.00 & 20.00 & $\begin{array}{l}88 \pm \\
3.2\end{array}$ & $2.8 \pm 3.4$ \\
\hline 7 & 6000 & 62.50 & 20.00 & $\begin{array}{l}92 \pm \\
2.5\end{array}$ & $2.6 \pm 3.6$ \\
\hline 8 & 4000 & 62.50 & 15.00 & $\begin{array}{l}83 \pm \\
2.7\end{array}$ & $2.5 \pm 1.6$ \\
\hline 9 & 6000 & 70.00 & 15.00 & $\begin{array}{l}80 \pm \\
1.4\end{array}$ & $2.1 \pm 3.2$ \\
\hline 10 & 6000 & 62.50 & 20.00 & $\begin{array}{l}92 \pm \\
2.1\end{array}$ & $\begin{array}{l}2.57 \pm \\
4.1\end{array}$ \\
\hline 11 & 4000 & 70.00 & 20.00 & $\begin{array}{l}77 \pm \\
1.7\end{array}$ & $2.6 \pm 2.3$ \\
\hline 12 & 6000 & 62.50 & 20.00 & $\begin{array}{l}92 \pm \\
2.5\end{array}$ & $\begin{array}{l}2.59 \pm \\
3.5\end{array}$ \\
\hline 13 & 8000 & 55.00 & 20.00 & $\begin{array}{l}87 \pm \\
2.3\end{array}$ & $3.9 \pm 1.4$ \\
\hline 14 & 6000 & 62.50 & 20.00 & $\begin{array}{l}92 \pm \\
1.9\end{array}$ & $2.6 \pm 3.3$ \\
\hline 15 & 6000 & 70.00 & 25.00 & $\begin{array}{l}77 \pm \\
1.6\end{array}$ & $2.4 \pm 2.2$ \\
\hline 16 & 8000 & 62.50 & 25.00 & $\begin{array}{l}92 \pm \\
1.2\end{array}$ & $2.8 \pm 4.2$ \\
\hline 17 & 4000 & 62.50 & 25.00 & $\begin{array}{l}87 \pm \\
3.1\end{array}$ & $2.7 \pm 3.9$ \\
\hline
\end{tabular}


The mathematical correlation amongst the independent variables and dependent variable in the response is explained by the second-order polynomial using Eq. (3).

$Y=\gamma_{0}+\gamma_{a} A+\gamma_{b} B+\gamma_{c} C+\gamma_{a a} A^{2}+\gamma_{b b} B^{2}+\gamma_{c c} C^{2}+\gamma_{a b} A B+\gamma_{a c} A C+\gamma_{b c} B C(3)$

Where $Y$ is the predicted response, $Y_{0}$ is the model constant, $A, B$, and $C$ are independent variables, ya, $Y_{b}$ and $\gamma_{c}$ are linear coefficients and $\gamma_{a b}, \gamma_{a c}$ and $\gamma_{b c}$ are cross-product coefficients, and $\gamma_{a a}, \gamma_{b b}$ and $\gamma_{c c}$ are the quadratic coefficients.

\subsubsection{Model fitting, statistical analysis, and numerical optimization}

To fit experimental data to the second-order mathematical polynomial regression model, a design expert (11) software was used as a regression analyzing tool. The statistical importance evaluation of the model was determined using ANOVA and optimization was done numerically using the design expert software.

\subsection{Characterization of cellulose and cellulose nanocrystals from millet husk}

\subsubsection{Fourier transform infrared spectroscopy (FTIR)}

Fourier transform infrared spectroscopy analysis of samples was performed using a VARIAN 7000 spectrometer. For each spectrum, 15 scans were accumulated over a resolution of $4 \mathrm{~cm}^{-1}$ and a range of $500-4500 \mathrm{~cm}^{-1}$.

\subsubsection{Scanning electron microscopy (SEM)}

Scanning electron micrograph of samples was done using a Philips XL 30FEG scanning electron microscope. All samples were coated with platinum using the sputtering technique.

\subsubsection{X-Ray diffraction (XRD)}

X-ray diffraction of samples was carried out using Cu ka radiation source in a Phillips X'pert Model 0993. The diffraction intensity was recorded between 5 and $90^{\circ}$ ( $2 \theta$ angle range) with a scanning speed of $0.4^{\circ} \mathrm{C}$ per min. The relative crystallinity index of the model was calculated by following Eq. (4)(Yalç et al. 2019).

$\mathrm{Cl}(\%)=\frac{\mathrm{I}_{02}-\mathrm{I}_{\mathrm{an}}}{\mathrm{I}_{02}} \times 100(4)$

$\mathrm{I}_{02}$ is the maximum diffraction intensity of the plane and $\mathrm{I}_{\mathrm{an}}$ represents the diffraction intensity of the amorphous part.

\subsubsection{Thermogravimetric analysis (TGA)}




\section{Results And Discussion}

\subsection{The development of quadratic for predicting yield and swelling capacity of CNCs}

The insignificant terms were eliminated using the Fischer's test in design expert software and the resulting final equation for predicting the yield and swelling capacity of CNCs are shown in Eq. (7) and Eq. (8) respectively.

Yield $(\%)=91.48+4.04 A+0.59 B+0.83 C-0.90 A B+0.81 A C-0.19 B C-1.22 A^{2}-9.31 B^{2}-3.54 C^{2}(7)$

$\operatorname{SWC}(\%)=2.58+0.09 A-0.46 B+0.06 C+0.05 A B-0.01 A C+0.19 B C+0.33 A^{2}+0.32 B^{2}-0.25 C^{2}(8)$

The negative and positive signs in the quadratic model to predict the yield and swelling capacity of CNCs expresses the antagonist effect and synergic effect in the model.

The regression coefficient $\left(R^{2}\right)$ values of the obtained models are 0.989 for the yield and 0.979 for the swelling capacity of CNCs. This means that 98.9 and $97.9 \%$ of the experimental data can be explained by the model for the yield and swelling capacity of CNCs as shown in Fig. 1.

\subsection{ANOVA for regression results for yield and swelling capacity of CNCs}

Table 3 and Table 4 show the ANOVA for the regression model for predicting the yield and swelling of CNCs respectively. The quadratic model equations show that $F=672.80$ and $F=413.55$ for the yield and swelling capacity of CNCs respectively with $\mathrm{P} \otimes 0.0001$ suggest that the models are significant in predicting yield and the swelling capacity. As shown in Table 3 from the ANOVA results for predicting the yield of CNCs it was observed that the homogenization speed and acid to cellulose ratio individual terms are significant terms in the model while the acid concentration term is insignificant. In the case, ANOVA results shown in Table 4 for predicting the swelling capacity of CNCs in all individual terms are significant in the model. The interaction terms are insignificant while all quadratic terms are significant in the model for predicting the yield and swelling capacity of CNCs. 
Table 3

ANOVA for regression model equation for the yield of CNCs when insignificant terms are removed.

\begin{tabular}{|c|c|c|c|c|c|c|}
\hline Source & $\begin{array}{l}\text { Sum of } \\
\text { Squares }\end{array}$ & Df & $\begin{array}{l}\text { Mean } \\
\text { Square }\end{array}$ & F-value & $\mathrm{p}$-value & Significance \\
\hline Model & 594.12 & 9 & 66.01 & 672.80 & $\begin{array}{l}< \\
0.0001\end{array}$ & significant \\
\hline $\begin{array}{l}\text { A-Homogenization } \\
\text { speed }\end{array}$ & 130.49 & 1 & 130.49 & 1329.95 & $\begin{array}{l}< \\
0.0001\end{array}$ & \\
\hline B-Acid concentration & 2.87 & 1 & 2.87 & 29.23 & 0.001 & \\
\hline $\begin{array}{l}\text { C-Acid to cellulose } \\
\text { ratio }\end{array}$ & 5.51 & 1 & 5.51 & 56.17 & 0.0001 & \\
\hline$A B$ & 3.26 & 1 & 3.26 & 33.21 & 0.0007 & \\
\hline AC & 2.66 & 1 & 2.66 & 27.08 & 0.0012 & \\
\hline $\mathrm{BC}$ & 0.14 & 1 & 0.14 & 1.47 & 0.0264 & \\
\hline$A^{2}$ & 6.31 & 1 & 6.31 & 64.26 & $<.0001$ & \\
\hline $\mathrm{B}^{2}$ & 364.85 & 1 & 364.85 & 3718.53 & $\begin{array}{l}<.0001 \\
0.00\end{array}$ & \\
\hline $\mathrm{C}^{2}$ & 52.65 & 1 & 52.65 & 536.63 & $\begin{array}{l}< \\
0.0001\end{array}$ & \\
\hline Residual & 0.68 & 7 & 0.098 & & & \\
\hline
\end{tabular}


Table 4

Results of ANOVA for regression model for the swelling capacity of CNCS when insignificant terms are removed.

\begin{tabular}{|c|c|c|c|c|c|c|}
\hline Source & $\begin{array}{l}\text { Sum of } \\
\text { Squares }\end{array}$ & Df & $\begin{array}{l}\text { Mean } \\
\text { Square }\end{array}$ & F-value & p-value & Significance \\
\hline Model & 3.05 & 9 & 0.3394 & 413.55 & $\begin{array}{l}< \\
0.0001\end{array}$ & significant \\
\hline $\begin{array}{l}\text { A-Homogenization } \\
\text { speed }\end{array}$ & 0.0648 & 1 & 0.0648 & 78.96 & $<.0001$ & \\
\hline B-Acid concentration & 1.76 & 1 & 1.76 & 2141.81 & $\begin{array}{l}< \\
0.0001\end{array}$ & \\
\hline C-Acid to ratio & 0.0378 & 1 & 0.0378 & 46.07 & 0.0003 & \\
\hline$A B$ & 0.0001 & 1 & 0.0001 & 0.1218 & 0.7373 & \\
\hline$A C$ & 0.0004 & 1 & 0.0004 & 0.4874 & 0.5076 & \\
\hline $\mathrm{BC}$ & 0.038 & 1 & 0.038 & 46.33 & 0.0003 & \\
\hline$A^{2}$ & 0.4704 & 1 & 0.4704 & 573.17 & $\begin{array}{l}<.0001 \\
0.00\end{array}$ & \\
\hline$B^{2}$ & 0.4359 & 1 & 0.4359 & 531.11 & $<.0001$ & \\
\hline $\mathrm{C}^{2}$ & 0.27 & 1 & 0.27 & 329.04 & $\begin{array}{l}<.0001 \\
0.0\end{array}$ & \\
\hline Residual & 0.0057 & 7 & 0.0008 & & & \\
\hline
\end{tabular}

\subsection{The effect of process variables on the yield and swelling capacity of CNCs from cellulose.}

\subsubsection{Effects of homogenization speed and acid concentration on the yield of CNCs}

Figure 2 shows the effect of homogenization speed and acid concentration on the yield of CNCs; the acid to cellulose mass ratio is held constant at $20 \mathrm{wt} \%$. At high acid concentration, the yield of CNCs is much higher than at low acid concentration. This may be attributed to the fact that at low acid concentration the acid can't access and attack the amorphous regions of the cellulose. At a high acid concentration, as time and homogenization speed is increased, the glucose may be generated as a result of the degradation of the cellulose and hence a reduction in the number of cellulose nanocrystals produced.

As the homogenization speed is increased the yield of CNCs increases this is because homogenization speed increases the chances of which the cellulose particles are distributed throughout the sulphuric acid. 
Another explanation could be that as homogenization speed is increased there is more collision between the cellulose and the sulphuric acids which breaks down the glycosidic bond between cellulosic chains which results in reduced amorphous chains and more crystalline structure.

\subsubsection{Effects of acid to cellulose ratio and acid concentration on the yield of CNCs}

Figure 3 , shows the effect of acid to cellulose ratio and acid concentration on the yield of CNCs, the homogenization speed is held constant at $6000 \mathrm{rpm}$. At higher acid, to cellulose mass ratio the yield of CNCs is higher than at low acid to cellulose ratio. This is because there is more cellulose to be attacked per unit volume of acid and hence more CNCs. As the acid concentration is increased the yield increases to a maximum level and then decreases. The main reason could be as the acid concentration is increased the crystalline part of the cellulose decomposes resulting in less yield of CNCs and also the glucosidic bond between cellulosic chains breaks down, resulting in shorter chains with irregular structure (Henschen et al. 2019; Souza et al. 2017).

\subsubsection{Effects of homogenization speed and acid concentration on the swelling capacity of CNCs}

Figure 4, shows the effect of homogenization speed and acid concentration on the swelling capacity of $\mathrm{CNCs}$; the acid to cellulose ratio is held constant at $20 \mathrm{wt} \%$. At high acid concentrations, the swelling capacity of CNCs is much lower than at low acid concentrations. The explanation could be the generation of glucose at the beginning process as a result of degradation which reduces the amount of CNCs and hence lowering the swelling capacity at high acid concentration. As the homogenization speed is increased the swelling capacity decreases and then increases (Minimax behavior). The reason could be there is no enough time to allow the sulphuric acid to diffuse into the chains of the cellulose. As the homogenization speed is increased, the breaking of the cellulose configuration occurs and their conversion to nanocellulose, causes extreme modifications to occur in the physicochemical attributes increasing the swelling capacity (Lei et al. 2019; Wang et al. 2015).

\subsubsection{Effects of acid to cellulose ratio and acid concentration on the swelling of CNCs}

Figure 5, shows the effect of acid to cellulose ratio and acid concentration on the swelling of CNCs; the homogenization speed is held constant at $6000 \mathrm{rpm}$. At low acid, to cellulose ratio, the swelling capacity is lower than at high acid to cellulose ratio. This is because there is more cellulose to be attacked per unit volume of acid and hence swelling capacity of CNCs increases. As the acid concentration is increased the swelling capacity decreases since the degradation starts with the most accessible region of the cellulose fiber and this reduces the end groups and the crystalline regions drastically and hence the swelling capacity drops (Lei et al. 2019; Chen et al. 2012).

\subsection{Individual influence of process variables on the yield and swelling capacity of CNCs from cellulose.}


As shown in Fig. 6, the perturbation plot shows the effect of process variable on the the yield and swelling capacity of CNCs from cellulose. Influence of one factor was evaluated and plotted alongside the yield and the swelling capacity while the other variabless were retained at a constant level. As shown in Fig. 6A, the homogenization speed and acid to cellulose ratio posses a great influence on the yield of CNCs from cellulose in comparison to the acid concentration. As shown in Fig. 6B, for the swelling capacity of CNCs, the homogenization speed and acid concentration posses a great influence while the acid to cellulose ratio shows the least influence.

From the perturbation plot, the yield and swelling capacity of CNCs from cellulose decreases as the acid concentration and acid to cellulose ratio is increased and increases with a increase of the homogenization speed. The result is in excellent agreement with the result acquired from the analysis of variance (ANOVA).

\subsection{Numerical optimizations}

The numerical optimization technique in the design expert software was used due to the maximum and minimum detected in the three-dimensional response surfaces. The objective function which is the yield and swelling capacity of CNCs was set at a maximum approach and all the other process variables namely homogenization speed, acid concentration, and acid to cellulose ratio were fixed at the range for optimization. the numerical optimization analysis results showed that the maximum yield of CNCs from cellulose was $93.12 \%$ and was obtained at homogenization speed, acid concentration, and acid to cellulose ratio of $7464.0 \mathrm{rpm}, 63.40 \mathrm{wt} \%$, and $18.83 \mathrm{wt} \%$ respectively. While the maximum swelling capacity of $2.81 \%$ was obtained at homogenization speed, acid concentration, and acid to cellulose ratio of $80000 \mathrm{rpm}, 62.5 \mathrm{wt} \%$, and $25 \mathrm{wt} \%$ respectively.

For this optimization, the desirability of 0.986 and 0.996 was obtained for yield and swelling capacity of CNCs respectively, which indicates that the response is inside the desirable limits and this suggests that the optimized operational conditions that can be trusted in achieving the maximum yield and swelling capacity of CNCs provided by the model.

\section{Characterization Results}

\subsection{Fourier-transform infrared spectroscopy (FTIR)Analysis}

FTIR functional groups for cellulose and cellulose nanocrystals (CNC) are depicted in Fig. 7. The wideband between $3100-3600 \mathrm{~cm}^{-1}$ is assigned to the vibration $0-\mathrm{H}$ group and it is attributed to hydrogen bonds due to molecular interactions in cellulose. Also, the bands at $2880 \mathrm{~cm}^{-1}$ and $2780 \mathrm{~cm}^{-1}$ are corresponding to the stretching vibration $\mathrm{C}-\mathrm{H}$ group. The band at $1650 \mathrm{~cm}^{-1}$ present for CNCs is assigned to the $\mathrm{O}-\mathrm{H}$ group. Conversely, this band was not existing in the original cellulose (Hemmati et al. 2018). This factor may be related to the sulfate groups existing on the external surface of the cellulose nanocrystals in the aqueous phase of CNCs, which will increase the hydrophilicity of the CNCs. The band at $1600 \mathrm{~cm}^{-1}$ is assigned to $\mathrm{C}=\mathrm{C}$, which represents the magnetism of the aromatic cycle in lignin 
formation in cellulose, it was degraded by acid hydrolysis in the CNCs. The band at $1430 \mathrm{~cm}^{-1}$ is linked to the $\mathrm{OH}$ and $\mathrm{C}-\mathrm{H}$ group available in the cellulose, but the group is drastically reduced in the CNCs due to the hydrolysis process (Meng et al. 2019). The band at $1320 \mathrm{~cm}^{-1}$ is assigned to the bending vibration of $\mathrm{CH} 2$. Other band includes $1030 \mathrm{~cm}^{-1}$ for morphological modification in $\mathrm{C}-\mathrm{O}$ and $890 \mathrm{~cm}-1$ which shows the common configuration of cellulose with the $\beta$ glycoside bonds in the glucose ring.

\subsection{X-ray diffraction (XRD) pattern}

Figure 8. elucidates the XRD analysis of cellulose and CNCs. Three common peaks were observed for cellulose and CNCs at $2 \theta$ angles of $16.6^{\circ}, 27.4^{\circ}$, and $40.0^{\circ}$ regions. The crystalline index of cellulose was $48 \%$ based on Fig. 8 . The alkali hydrolysis and lignin in cellulose are removed by concentrated sulfuric acid, the amorphous region in the cellulose configuration is detached and the crystallinity index is improved (Oyewo et al. 2019). After acid hydrolysis, the crystallinity index was around $70 \%$. The $\%$ degree of crystallinity is influenced by the source of cellulose, the period of CNCs purification, and the process conditions of hydrolysis. There is a straight connection between the degree of crystallinity and the hardness of the cellulose. The harder the cellulose, the higher the crystallinity index (Ishak et al. 2019). In other studies, related to this work, the crystallinity index of peanut shells and pine bark are $36.7^{\circ}$ and $55^{\circ}$ respectively, which is similar to the crystallinity index measured in this study.

\subsection{Thermogravimetric analysis (TGA)}

The thermal stability of cellulose and cellulose nanocrystals (CNCs) is presented in Fig. 9. As it can be depicted in the graph the temperature decreased slightly between 60 and $100^{\circ} \mathrm{C}$ for both cellulose and CNCs graphs, indicating the loss of water due to evaporation. The weight loss of both samples at this stage is less than $6 \%$, and for cellulose, there was a further loss at the temperature range between 260 to $400^{\circ} \mathrm{C}$, this is associated with the decomposition of alpha-cellulose and lignin. At this phase, the mass loss of $85 \%$ of the cellulose occurs. This may be linked to the destruction of chains in cellulose and due to the disintegration of glycosyl cellulose chains and decarboxylation (Hemmati et al. 2018). At temperatures above $400^{\circ} \mathrm{C}$, the mass loss is assigned to oxidation and the formation of residual ash in low-weight gases. At this phase, the residual content is less than $10 \%$ at $600^{\circ} \mathrm{C}$.

The CNCs showed a dissimilar thermal stability trend as compared to cellulose. The main mass loss of the CNCs occurred at the temperature range of between 240 to $380^{\circ} \mathrm{C}$ and the sample lost $79 \%$ of its weight. For the $\mathrm{CNCs}$, degradation occurred over a wider temperature range as compared to cellulose. The large surface area of CNCs can play a key role in decreasing the thermal stability because in the CNCs the contact surface advances the heat transfer. Furthermore, through acid hydrolysis with sulfuric acid, both amorphous and crystalline structures decompose, this fact makes the arrangements within the CNCs are more sensitive to heat ( Leszczy et al. 2018).

\subsection{Scanning electron microscopy (SEM) analysis}


Figure 10, shows the SEM images of cellulose and cellulose nanocrystals (CNCs). The SEM images depict that the alpha-cellulose fibers were relatively easy to see and more regular surfaces were observed after the elimination of the non-cellulosic components. On the other hand, the cellulose nanocrystals (CNCs) cover the surface in the form of short fibers and fine fibers, this is probably because sulfuric acid penetrated the amorphous region of cellulose, causing the hydrolysis and degradation of glucopyranose linkage. The actual structure of the cellulose nanocrystals is visible, probably due to the drying process, the presence of nanocrystals cluster around ice crystals is the result of the large number of hydrogen bonds formed between the surfaces.

\section{Conclusion}

This study shows that it is possible to extract cellulose nanocrystals (CNCs) from cellulose using millet husk residue waste. A Box Behnken design was used to investigate and optimize the effect of homogenization speed, acid concentration, and acid to cellulose ratio on the yield and swelling capacity of CNCs. Results show the yield and swelling capacity of CNCs from cellulose decreases as the acid concentration and acid to cellulose ratio is increased and increases with an increase in homogenization speed. The maximum yield of CNCs of $93.12 \mathrm{wt} \%$ was obtained at homogenization speed, acid concentration, and acid to cellulose ratio of $7464.0 \mathrm{rpm}, 63.40 \mathrm{wt} \%$, and $18.83 \mathrm{wt} \%$ respectively. The optimum swelling capacity of $2.81 \%$ was obtained at homogenization speed, acid concentration, and acid to cellulose ratio of $8000 \mathrm{rpm}, 62.5 \mathrm{wt} \%$, and $25 \mathrm{wt} \%$ respectively. A mathematical model was obtained to predict the yield and the swelling capacity of cellulose nanocrystals with $\mathrm{R}^{2}$ of the value of $98.9 \%$ and $97.9 \%$ respectively. The cellulose and nano-cellulose obtained were characterized using transform infrared microscopy (FTIR), X-ray diffraction (XRD), thermogravimetric analysis (TGA), and scanning electron microscopy (SEM). The TGA showed that the thermal stability of cellulose was higher than that of CNCs, FTIR results showed function group of CNCs and cellulose were similar, SEM image of CNCs is porous and displayed narrow particle size and needle-like morphology as compared to cellulose and XRD pattern presented an increase in the intensity of CNCs.

\section{Abbreviations}

CNCs

Cellulose nanocrystals; FTIR:Fourier transform infrared; SEM:Scanning electron microscope; X-ray diffraction (XRD); Thermogravimetric analysis (TGA).

\section{Declarations}

\section{Acknowledgments}

The authors acknowledge the financial support provided by the Paper Manufacturers Association of South Africa (PAMSA) and Department of Science and Innovation (South Africa). 


\section{Authors' contributions}

$\mathrm{MB}$-conceptualization, data collection, investigation, and writing the original draft. HR-supervision, review, validation, and editing.

\section{Funding}

Paper Manufacturers Association of South Africa (PAMSA) and Department of Science and Innovation (South Africa).

\section{Availability of data and materials}

All data are available in this manuscript.

\section{Ethics approval and consent to participate}

Not applicable.

\section{Consent for publication}

Not applicable.

\section{Competing interests}

The authors declare that they have no competing interests.

\section{References}

1. Abdelraof, M, Hasanin MS, Farag MM, Ahmed HY (2019) Green synthesis of bacterial cellulose / bioactive glass nanocomposites: Effect of glass nanoparticles on cellulose yield, biocompatibility and antimicrobial activity. Int J Biol Macromol 138:975-985. https://doi.org/10.1016/j.jibiomac.2019.07.144

2. Awang NW, Ramasamy D, Kadirgama K, Samykano M, Najafi G, Azwadi N, Sidik C (2019) An experimental study on characterization and properties of nano lubricant containing Cellulose Nanocrystal (CNCs). Int J Heat Mass Transf 130:1163-1169. https://doi.org/10.1016/j.jijeatmasstransfer.2018.11.041

3. Chen D, Lawton D, Thompson MR, Liu Q (2012) Biocomposites reinforced with cellulose nanocrystals derived from potato peel waste. Carbohydr Polym 90:709-716. https://doi.org/10.1016/j.carbpol.2012.06.002

4. Du H, Liu W, Zhang M, Si C, Zhang X, Li B (2019) Cellulose nanocrystals and cellulose nano fibrils based hydrogels for biomedical applications. Carbohydr Polym 209:130-144. https://doi.org/10.1016/j.carbpol.2019.01.020 
5. Gopalan C, Ramashastri BV, Balasubramanian B V.(1989) Nutritive value of Indian foods (pp. 4791). New Delhi: ICMR Offset Press

6. Hemmati F, Mahdi S, Kashaninejad M, Barani M (2018) Synthesis and characterization of cellulose nanocrystals derived from walnut shell agricultural residues. Int J Biol Macromol 120:1216-1224. https://doi.org/10.1016/j.jibiomac.2018.09.012

7. Henschen J, Li D, Ek M (2019) Preparation of cellulose nanomaterials via cellulose oxalates. Carbohydr Polym 213:208-216. https://doi.org/10.1016/j.carbpol.2019.02.056

8. Hynninen V, Mohammadi P, Wagermaier W, Hietala S (2019) Methyl cellulose / cellulose nanocrystal nanocomposite fibers with high ductility. Eur Polym J 112:334-345.

https://doi.org/10.1016/j.eurpolymj.2018.12.035

9. Ishak NS, Ishak KMK, Bustami Y, Rokiah H (2019) ScienceDirect Evaluation of Cellulose Nanocrystals ( CNCs ) as Protein Adsorbent in stick water. Mater Today Proc 17:516-524. https://doi.org/10.1016/j.matpr.2019.06.330

10. Lei W, Zhou X, Fang C, Song Y, Li Y (2019) Eco-friendly waterborne polyurethane reinforced with cellulose nanocrystal from o ffi ce waste paper by two different methods. Carbohydr Polym 209:299-309. https://doi.org/10.1016/j.carbpol.2019.01.013

11. Leszczy A, Radzik P, Hara K, Pielichowski K (2018) Thermal stability of cellulose nanocrystals prepared by succinic anhydride assisted hydrolysis. Thermochimica Acta 663:145-156.. https://doi.org/10.1016/j.tca.2018.03.015

12. Meng F, Wang G, Du X, Wang Z, Xu S, Zhang Y (2019) Extraction and characterization of cellulose nanofibers and nanocrystals from liquefied banana pseudo-stem residue. Compos Part B 160:341347. https://doi.org/10.1016/j.compositesb.2018.08.048

13. Montgomery DC (2005) Design and Analysis of Experiments: Response surface method and designs. New Jersey: John Wiley and Sons, Inc.

14. Niamsap T, Tien N, Sukyai $P$ (2019) Production of hydroxyapatite-bacterial nanocellulose sca ff old with assist of cellulose nanocrystals. Carbohydr Polym 205:159-166.

https://doi.org/10.1016/j.carbpol.2018.10.034

15. Onur A, Ng A, Garnier G, Batchelor W (2018) Separation and Purification Technology Engineering cellulose fibre inorganic composites for depth filtration and adsorption. Sep Purif Technol 203:209216.https://doi.org/10.1016/j.seppur.2018.04.038

16. Oyewo OA, Mutesse B, Leswifi TY, Onyango MS (2019) Highly efficient removal of nickel and cadmium from water using sawdust- derived cellulose nanocrystals. J Environ Chem Eng 7:103251. https://doi.org/10.1016/j.jece.2019.103251

17. Priscila A, Silva M, Vitória A, Pontes SMA, Pereira ALS, De M, Filho MS, Rosa MF, Azeredo HMC (2019) Mango kernel starch films as affected by starch nanocrystals and cellulose nanocrystals. Carbohydr Polym 211:209-216. https://doi.org/10.1016/j.carbpol.2019.02.013

18. Naduparambath S, Purushothaman E (2016) Sago seed shell: determination of the composition and isolation of microcrystalline cellulose (MCC). Cellulose 23:1803-1812. 
https://doi.org/10.1007/s10570-016-0904-3

19. Shafiei M, Karimi K, Taherzadeh MJ (2010) Palm Date Fibers: Analysis and Enzymatic Hydrolysis. Int J Mol Sci 11:4285-4296. https://doi:10.3390/ijms11114285

20. Souza AG, De Kano, FS, Bonvent JJ (2017) Cellulose Nanostructures Obtained from Waste Paper Industry: A Comparison of Acid and Mechanical Isolation Methods. Mat Res 20:1-6.

https://doi.org/10.1590/1980-5373-MR-2016-0863 Materials Research. 2 1-6.

21. Wang C, Huang H, Jia M, Jin S, Zhao W, Cha R (2015) Formulation and evaluation of nanocrystalline cellulose as a potential disintegrant. Carbohydr Polym 130:275-279.

https://doi.org/10.1016/j.carbpol.2015.05.007

22. Wu W, Song R, Xu Z, Jing Y, Dai H, Fang G (2018) Sensors and Actuators B: Chemical Fluorescent cellulose nanocrystals with responsiveness to solvent polarity and ionic strength. Sensors Actuators B Chem 275:490-498. https://doi.org/10.1016/j.snb.2018.07.085

23. Yalç A, Ersus S, Cesur S (2019) Optimum alkaline treatment parameters for the extraction of cellulose and production of cellulose nanocrystals from apple pomace. . Carbohydr Polym 215:330-337. https://doi.org/10.1016/j.carbpol.2019.03.103

24. Zolgharnein J, Dalvand K, Rastgordani M, Zolgharnein P (2017) Adsorptive removal of phosphate using nano cobalt hydroxide as a sorbent from aqueous solution; multivariate optimization and adsorption characterization. Journal of Alloys and Compounds 725:006-1017. https://doi.org/10.1016/j.jallcom.2017.07.228

25. Zou S., Zou F, Ning J, Deng T, Yu D, Ye T, Xu D, Wang Z (2018) A stand-alone Co mineral deposit in northeastern Hunan Province, South China: Its timing, origin of ore fluids and metal Co, and geodynamic setting. Ore Geol Rev 92:42-60. https://doi.org/10.1016/j.oregeorev.2017.11.008

\section{Figures}



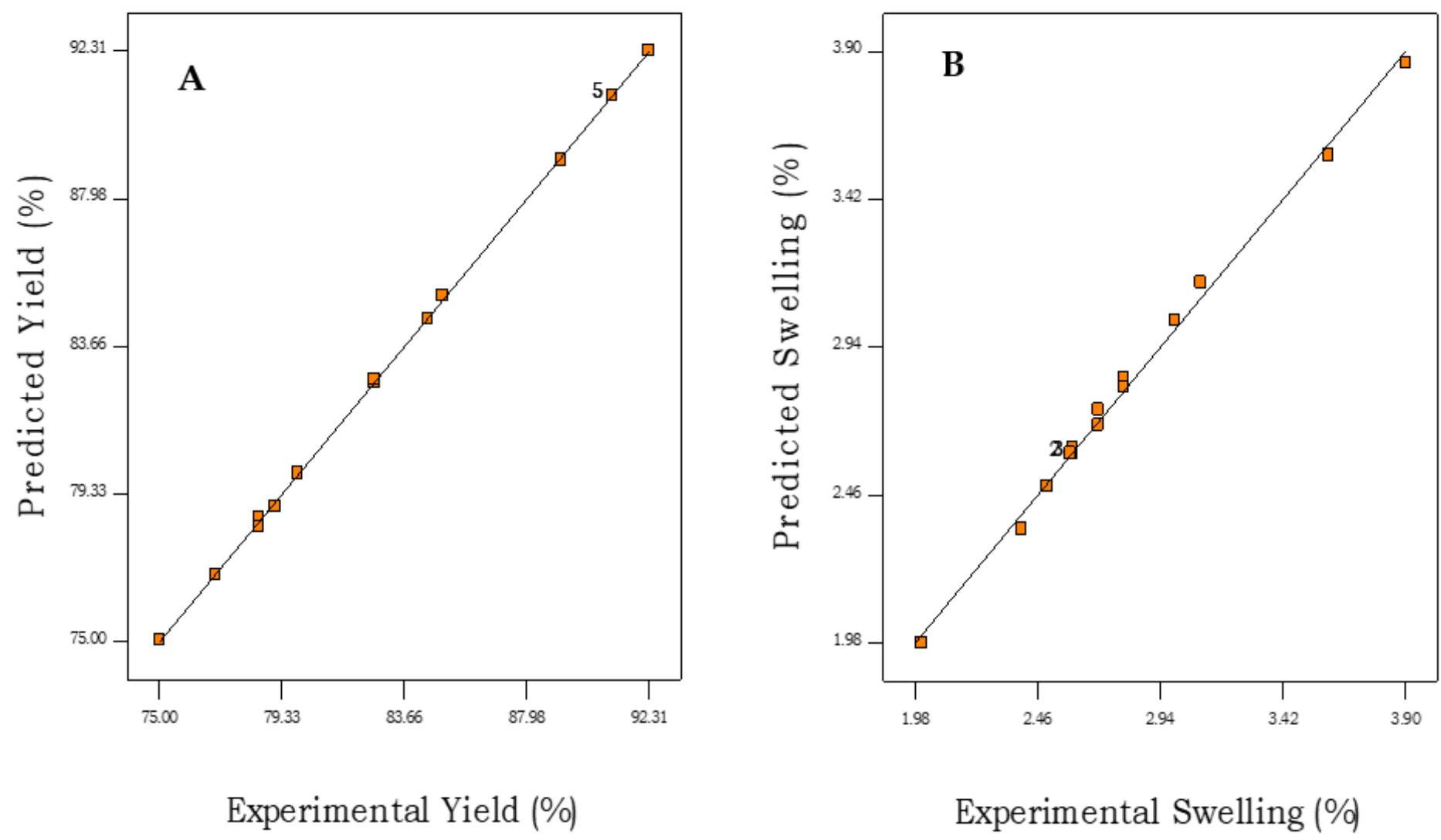

Figure 1

A plot between the predicted and experimental values for yield $(A)$ and $(B)$ for swelling capacity of CNCs.
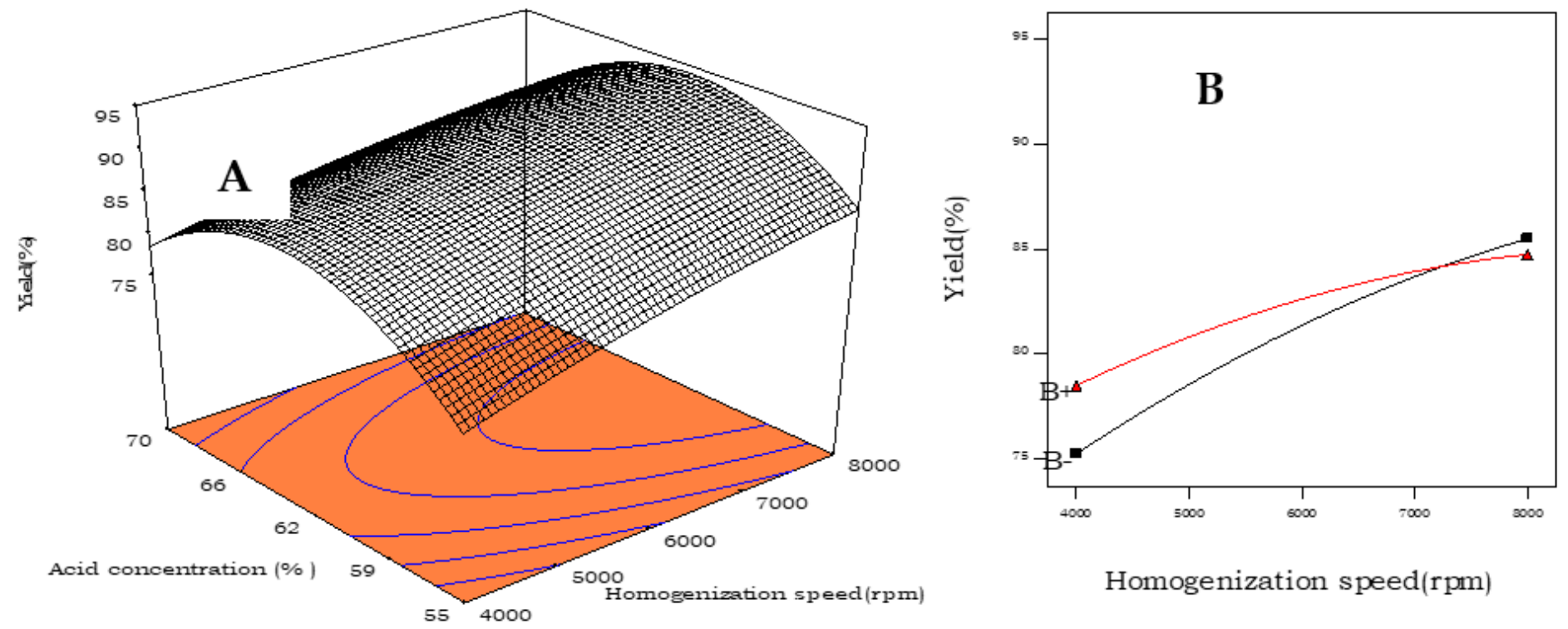

Homogenization speed(rpm)

Figure 2

Effect of homogenization speed and acid concentration on the yield of CNCs, (A) response surface and (B) two-dimension plot with acid concentration held at (-) $55 \mathrm{wt} \%$ and (+) $70 \mathrm{wt} \%$. 

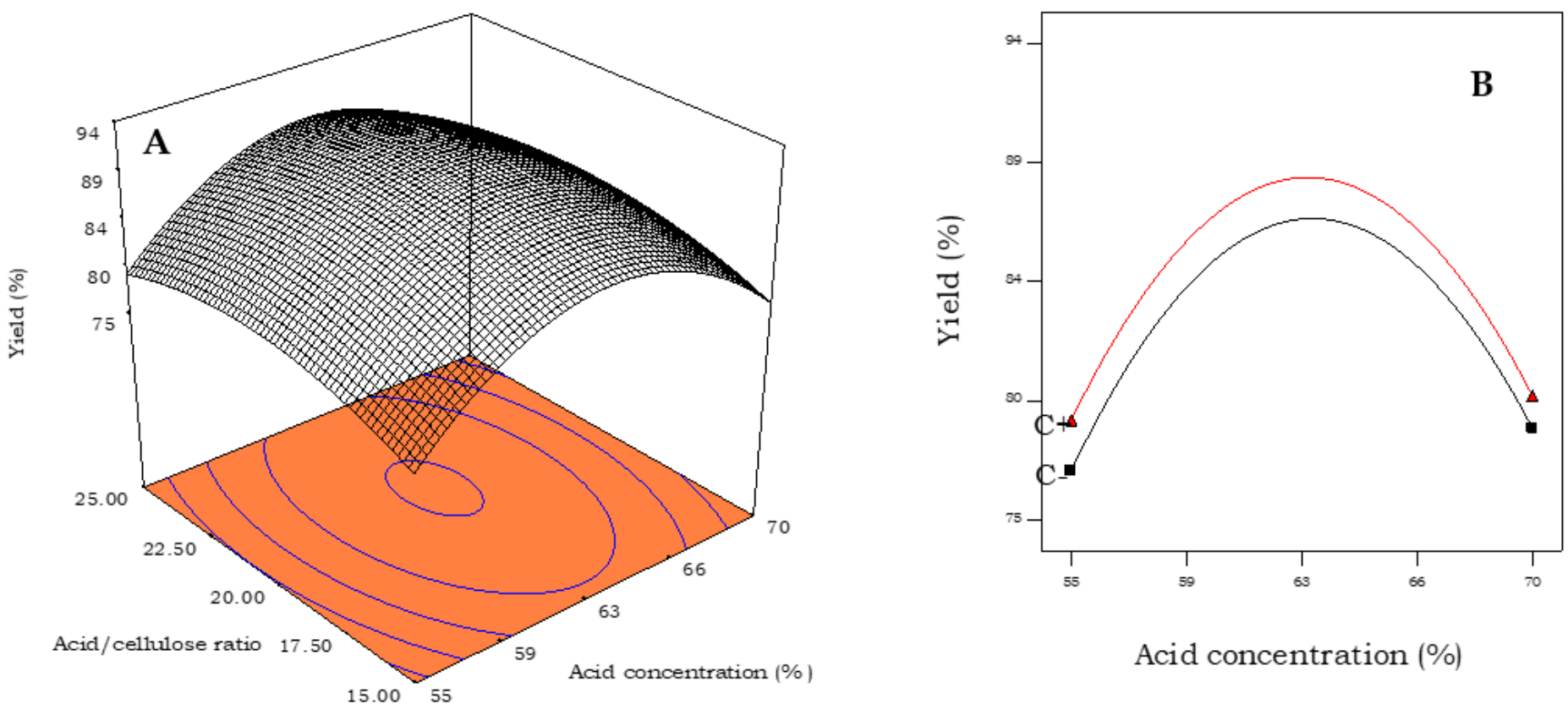

Figure 3

Effect of acid to cellulose ratio and acid concentration on the yield of CNCs, (A) response surface and (B) two-dimension plot with acid to cellululose ratio (wt \%) held at (-) $15 \mathrm{wt} \%$ and (+) $20 \mathrm{wt} \%$.
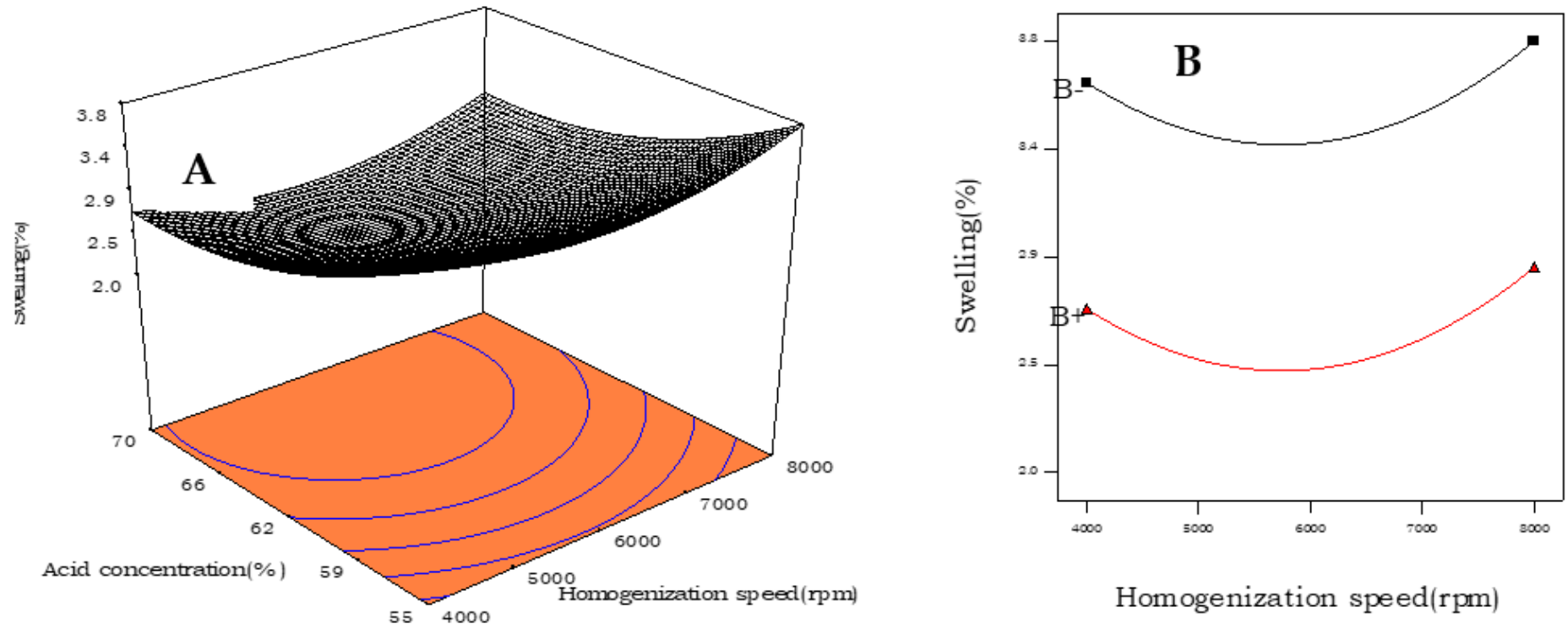

\section{Figure 4}

Effect of homogenization speed and acid concentration on the swelling capacity of CNCs, (A) response surface and (B) two-dimension plot with acid concentration held at (-) $55 \mathrm{wt} \%$ and (+) $70 \mathrm{wt} \%$. 

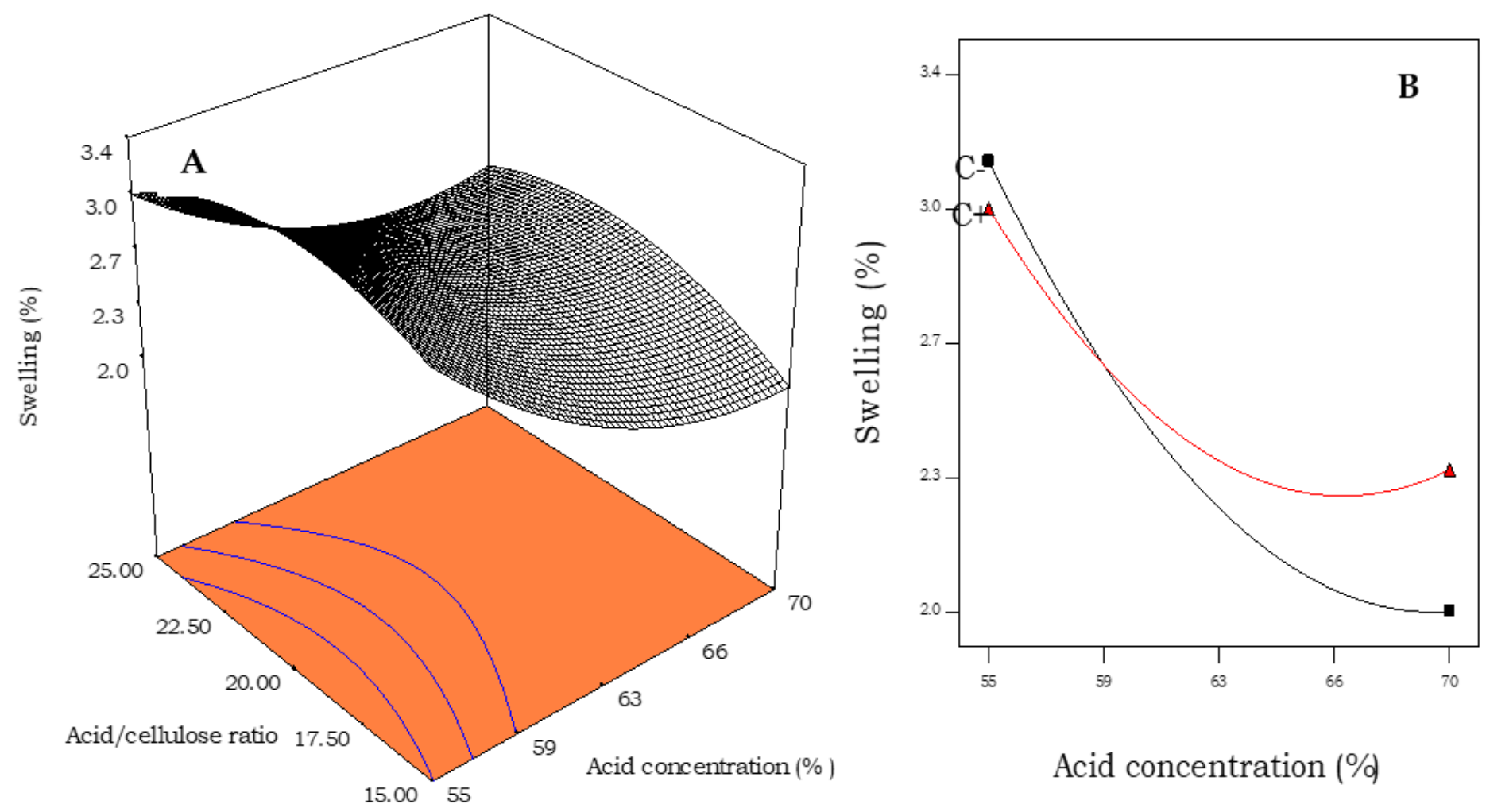

Figure 5

Effect of acid to cellulose ratio and acid concentration on the yield of CNCs, (a) response surface and (b) two-dimension plot with acid to cellulose mass ratio held at (-) $15 \mathrm{wt} \%$ and (+) $20 \mathrm{wt} \%$
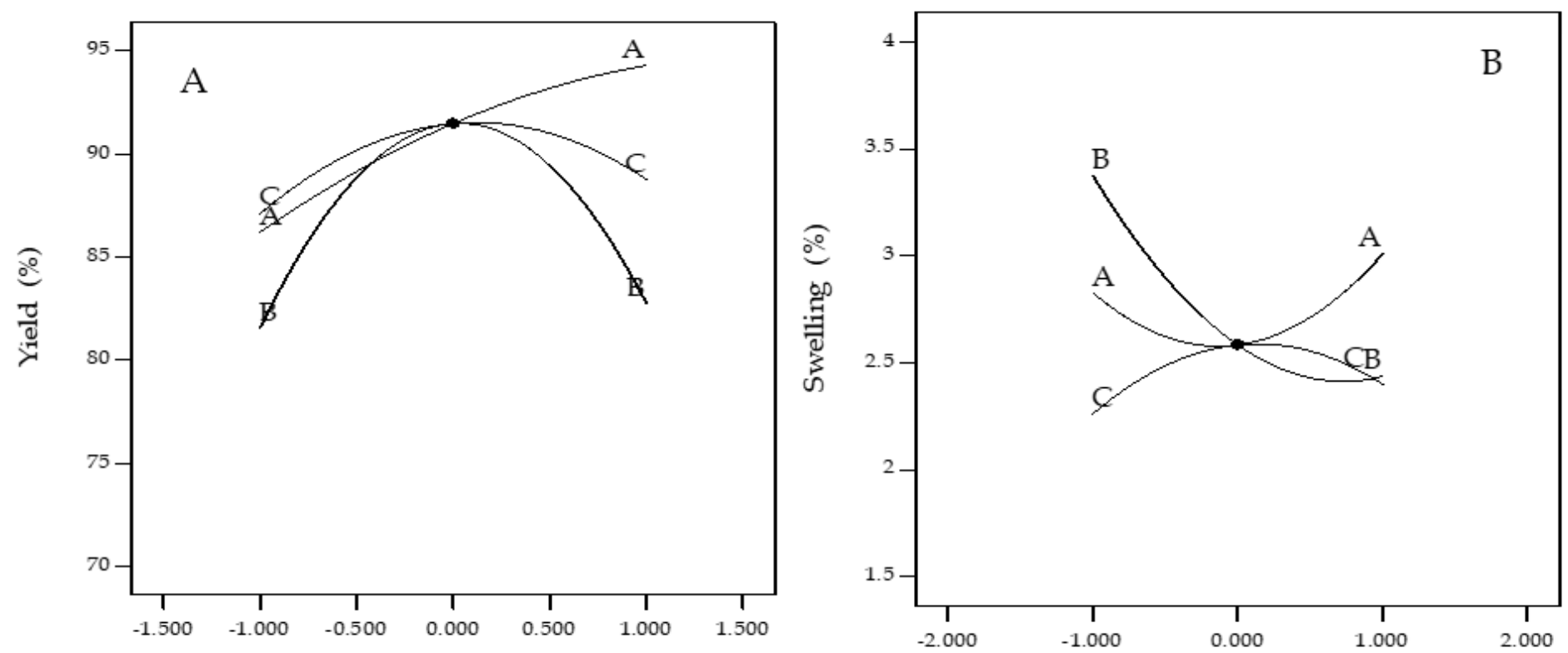

Figure 6 
Pertubation plots showing the effects of (A) homogenization speed, (B) acid concentration, and (C) cellulose to acid ratio on the yield and swelling capacity

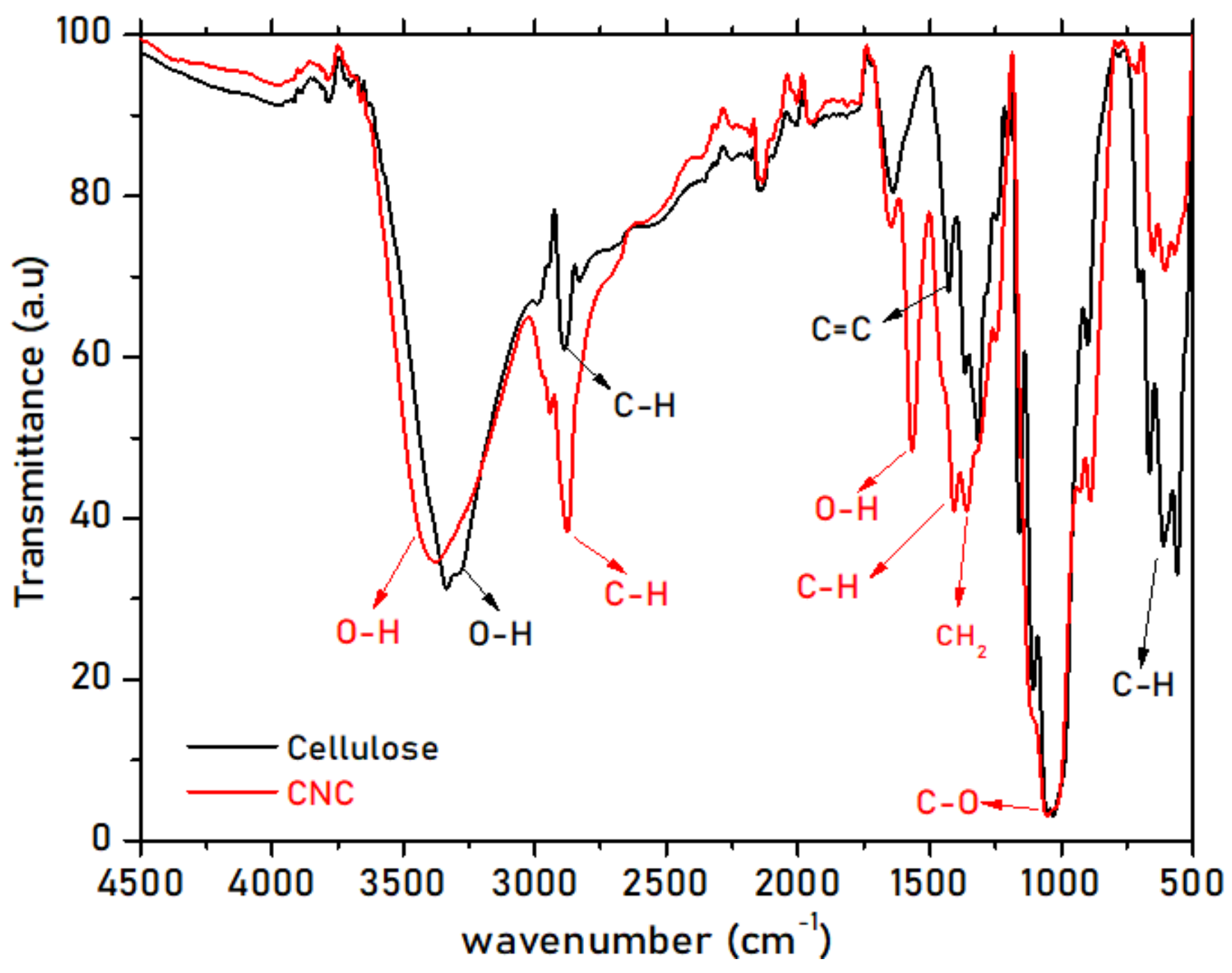

Figure 7

FTIR transmittance of cellulose and cellulose nanocrystals (CNCs) 


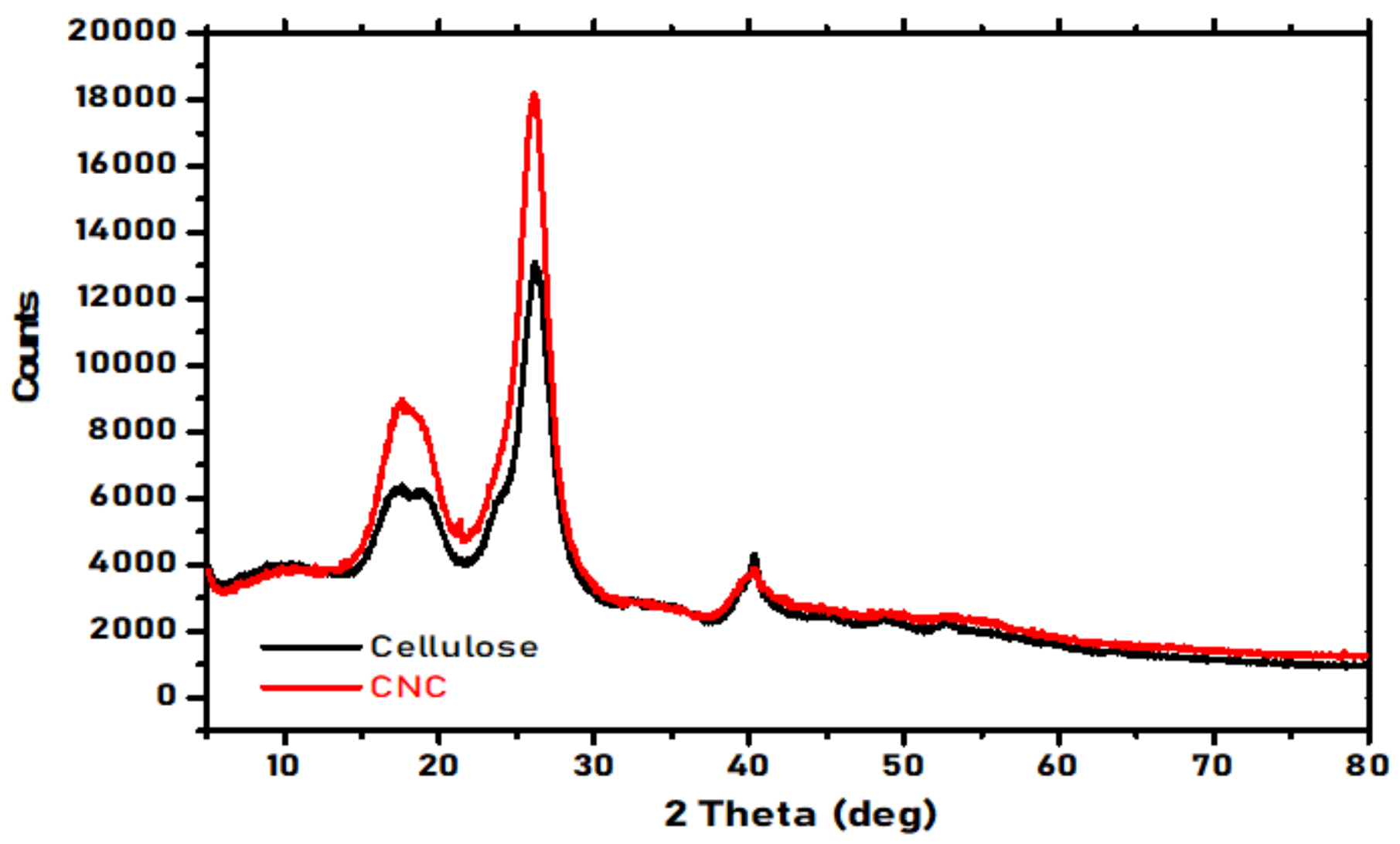

Figure 8

XRD patterns of cellulose and cellulose nanocrystals (CNCs) 


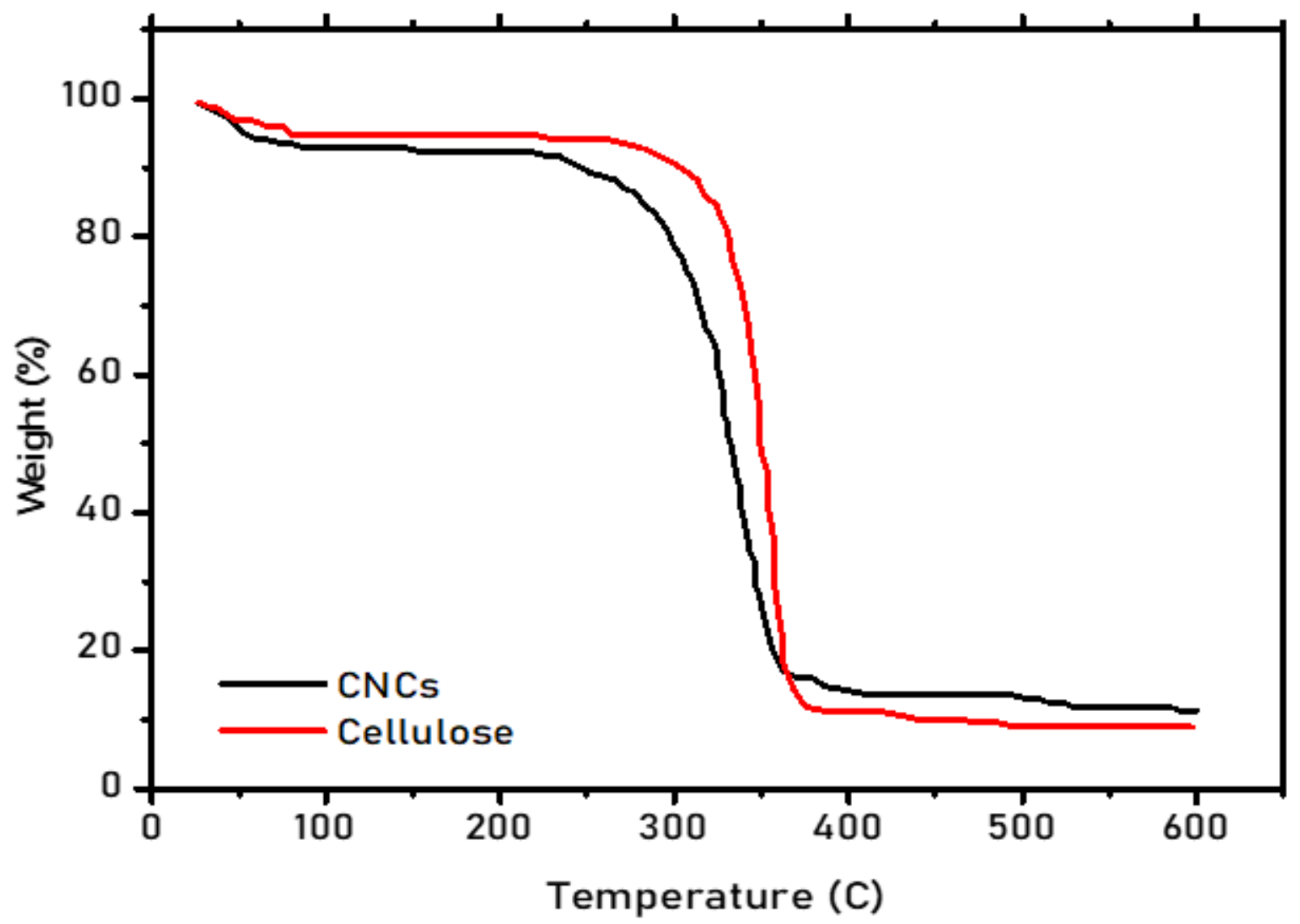

Figure 9

TGA graph for cellulose and cellulose nanocrystals CNCs
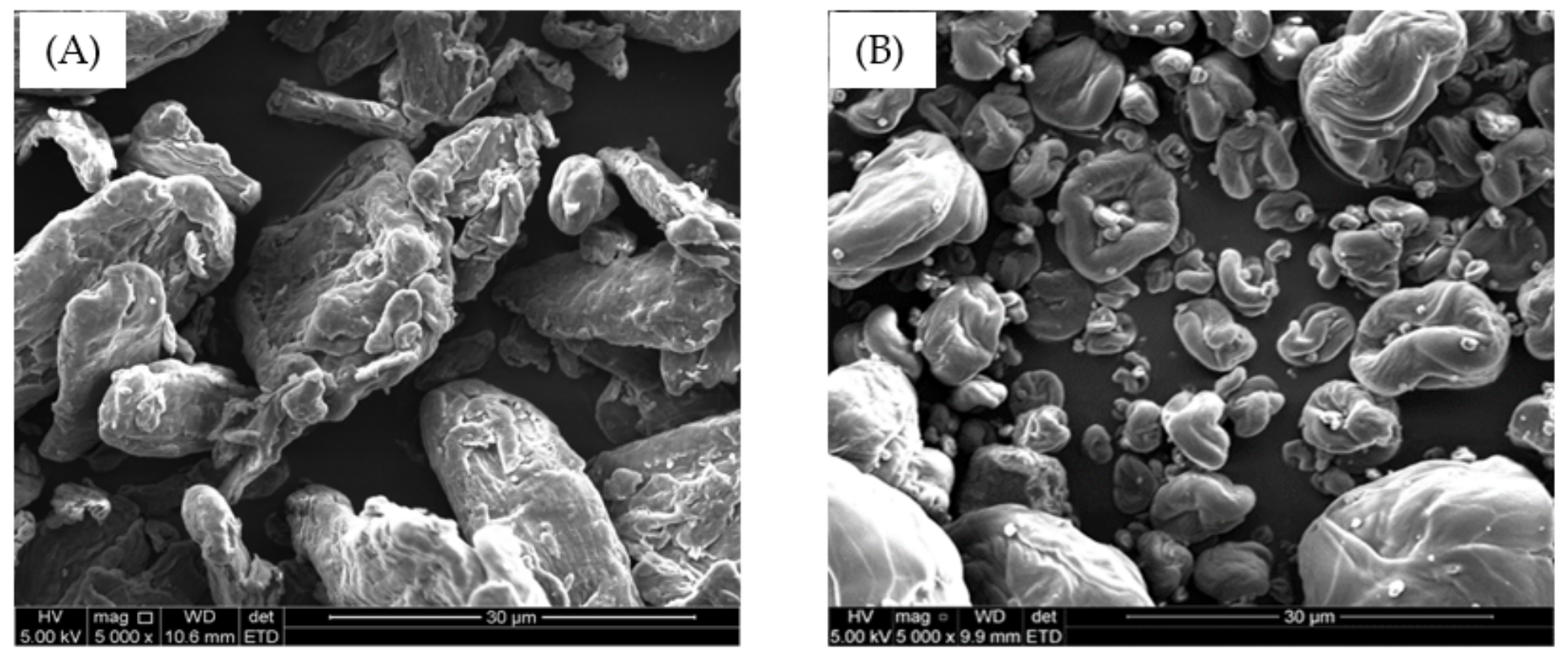

Figure 10

SEM image of cellulose (A) and cellulose nanocrystals (CNCs) (B) 


\section{Supplementary Files}

This is a list of supplementary files associated with this preprint. Click to download.

- graphicalabstract.docx 